Cereal Research Communications 43(2), pp. 344-352 (2015)

DOI: $10.1556 /$ CRC.2014.0033

First published online 25 September, 2014

\title{
Effect of Sulphur Fertilization on Yield and Quality of Wheat Grain
}

\author{
L. HŘIVNA ${ }^{1}$, B. KOTKOVÁ ${ }^{1}$ and I. BUREŠOVÁ ${ }^{2 *}$ \\ ${ }^{1}$ Department of Food Technology, Faculty of Agronomy, Mendel University in Brno, \\ Zemědělská 1, 61300 Brno, Czech Republic \\ ${ }^{2}$ Department of Food Technology, Faculty of Technology, Tomas Bata University in Zlín, \\ nám. T. G. Masaryka 5555, 76272 Zlín, Czech Republic \\ (Received 1 February 2014; Accepted 2 June 2014; \\ Communicated by J. Kubat)
}

\begin{abstract}
The influence of sulphur fertilization on plant dry weight, grain yield and quality of wheat grain (var. Mulan) was investigated. Wheat was grown in the small plot field experiments conducted in 2011-2012. At the beginning of tillering, the regenerative sulphur fertilization increased dry plant weight and sulphur concentration in dry matter by $28.1-43.2 \%$. Sulphur application reduced the number of unproductive tillers and increased the number of ears per unit area by $10-70 \%$. The highest grain yield was achieved after the application of solid fertilizers YaraBela SULFAN and fertilizer YaraVita Thiotrac applied in the late growing stages. Sulphur fertilization slightly improved the values of grain specific weight, protein content and Zeleny sedimentation volume, but the effect was not significant. The effect of fertilizer application significantly differed between the studied years.
\end{abstract}

Keywords: Triticum aestivum L., sulphur, fertilization, grain, quality

\section{Introduction}

Yield and bread-making quality of wheat grain is influenced by the growing conditions, genotype and fertilization (Johansson et al. 2004). Sulphur is an important and essential plant nutrient necessary for plant metabolism, growth and development. The average winter wheat sulphur consumption is about $25-30 \mathrm{~kg}$ of sulphur per hectare (Hagel 2005). The main biochemical role of sulphur is to form disulphide bridges between peptide chains and stabilise the protein structures (Hawkesford and De Kok 2006). Sulphur deficiency reduces the efficiency of nitrogen fertilization, increases losses of nitrate and reduces the number of grains per ears (Rasmussen et al. 1977; Mengel 1991; Schnug et al. 1993; Haneklaus et al. 1995; Hřivna et al. 1999; Hřivna and Richter 2002). Deficiency of this element can decrease grain yield and grain bread-making quality (Zhao et al. 1999a, b; Shahsavani and Gholami 2008). Sulphur deficiency is an important factor limiting the crop production in many regions around the world.

* Corresponding author; E-mail: buresova@ft.utb.cz; Phone: +420 576033333 
Before the application of sulphur fertilizers it is necessary to define the amount of sulphur required for proper plant growth and development (Dämmgen et al. 1998; Zhao et al. 1999b; Mathot et al. 2008; Zörb et al. 2010). The sulphur deficiency limit in wheat grain is defined as nitrogen:sulphur (N:S) ratio $\geq 17: 1$ or as sulphur concentration lower than $0.2 \%$ (Zhao et al. 1999a).

The aim of the study was to evaluate the effect of nitrogen and sulphur fertilization on the composition of plant matter, yield and quality of wheat grain.

\section{Material and Methods}

\section{Material}

The research was carried out on winter wheat var. Mulan. Wheat was grown in small field plots $21.6 \mathrm{~m}^{2}$ (ZP Agra Velký Týnec, Czech Republic) in 2011-2012. The plots are located in slightly warm and slightly humid climatic region. The soil can be characterized according to WRB classification as haplic Luvisols (haLV). The $\mathrm{pH}$ value and nutrient contents of the soil were determined using Mehlich III method (Zbíral 2002) before the experiments were conducted. The soil characteristics are presented in Table 1.

\begin{tabular}{lccccc}
\multicolumn{7}{c}{ Table 1. Agrochemical characteristics of soil } \\
\hline Year & $\mathrm{pH} / \mathrm{CaCl}_{2}$ & $\mathrm{P}$ & $\mathrm{K}$ & $\mathrm{Ca}$ & $\mathrm{Mg}$ \\
\cline { 3 - 6 } & & \multicolumn{5}{c}{$\mathrm{mg} \cdot \mathrm{kg}^{-1}$} \\
2011 & 5.640 & 38.6 & 148.4 & 1997 & 111.8 \\
2012 & 7.020 & 89.2 & 225.7 & 2600 & 107.4 \\
\hline
\end{tabular}

P: Phosphorus; K: Potassium; Ca: Calcium; Mg: Magnesium

\section{Fertilizer application}

The fertilizer was applied according to the scheme presented in Table 2. Each variant was grown in four replications.

Table 2. The total applied dose of nitrogen fertilizer and nitrogen fertilizer containing sulphur $\left(\mathrm{kg} \cdot \mathrm{ha}^{-1}\right)$

\begin{tabular}{llccc}
\hline Var. Fertilizer & N & S-Sulfan & S-Thiotrac \\
\hline 1 & LAV & 174 & & \\
2 & YaraBela SULFAN & 174 & 30 & 1.5 \\
3 & LAV + YV Thiotrac & 174 & 30 & 1.5 \\
4 & YaraBela SULFAN + YV Thiotrac & 174 & & 1.5 \\
5 & LAV + YV Thiotrac & 174 & 30 & 1.5 \\
6 & YaraBela SULFAN + YV Thiotrac & 174 & & \\
\hline
\end{tabular}

LAV: Ammonium nitrate with limestone $\left(27 \% \mathrm{~N}, 20 \% \mathrm{CaCO}_{3}\right)$, YaraBela SULFAN $(24 \% \mathrm{~N}+6 \% \mathrm{~S}+7 \%$ $\mathrm{CaO}$ ), YV Thiotrac (YaraVita Thiotrac) $300 \mathrm{~g} \mathrm{~S}, 200 \mathrm{~g} \mathrm{~N}$ in $1 \mathrm{~L}$ 


\section{Plant analysis}

Plant matter characteristics were tested during the growing period, according to the scheme shown in Table 3. The total nitrogen content was determined using the Dumas method (Zbíral et al. 2005). The plant was treated with the mixture of $\mathrm{H}_{2} \mathrm{O}_{2}$ and $\mathrm{HNO}_{3}$ before the determination of other nutrient characteristics. The samples were subsequently analysed according to Zbíral et al. (2005) using optical emission spectrometry with inductively coupled plasma ICP-OES. The harvested grain was subjected to analysis.

Table 3. Plant sampling during wheat growing stages

\begin{tabular}{llccc}
\hline Variant & Applied fertilizer & BBCH 28-30 & BBCH 39-43 & BBCH 65-70 \\
\hline 1 & LAV & + & + & + \\
2 & YaraBela SULFAN & + & + & + \\
3 & LAV + YV Thiotrac & & + & + \\
4 & YaraBela SULFAN + YV Thiotrac & & + & + \\
5 & LAV + YV Thiotrac & & + \\
6 & YaraBela SULFAN + YV Thiotrac & & & + \\
\hline
\end{tabular}

YV Thiotrac: YaraVita Thiotrac

\section{Grain quality}

Specific weight was assessed according to ISO 7971-2 (1995). It was measured as weight of grain per unit volume and the results were expressed in $\mathrm{kg} \cdot \mathrm{hl}^{-1}$. The proportion of front grain was determined using Czech technical standard ČSN 461011-7 (1988). Wheat grains were ground into wholemeal on a laboratory mill MILL 120 (Perten Instr). Hagberg falling number (ISO 3093 2004) was measured as the total time, in seconds, required to activate a viscometer stirrer and allow it to fall a predetermined distance through an aqueous gel prepared by heating a mixture of wholemeal and water in a viscometer tube. Protein content in dry matter was assessed using the Dumas combustion method according to ICC Standard no. 167 (2000). The total content of crude protein in dry matter was calculated as the nitrogen content multiplied by 5.7 and expressed in percent $(\mathrm{w} / \mathrm{w})$. Zeleny sedimentation volume was determined according to ISO 5529 (2007).

Each laboratory test was carried out on two test portions simultaneously or rapidly one after the other. The arithmetic mean of two determinations was taken as a result, if the conditions of repeatability given by standards were satisfied. If the absolute difference between two independent single test results, obtained using the same method on identical test material in the same laboratory by the same operator using the same equipment with a short interval of time was outside of standard limits, two determinations were carried out again.

\section{Statistical analysis}

Statistical data analysis was tested by two-factor analysis of variance followed by Tukey's test. Data were evaluated using STATISTICA 10.0 (StatSoft, Inc.). 


\section{Results}

The application of fertilizer YaraBela SULFAN containing sulphur had a positive effect on the values of plant weight and sulphur content in plant (Table 4). The apparent differences between the variants were observed 14 days after fertilization during BBCH 28-30 growing stages. The total sulphur uptake per plant was increased by 28.1 to $43.2 \%$ compared with the control sample.

The application of solid and liquid fertilizers containing sulphur improved the plant characteristics in the BBCH 39-43 growing stages in 2012 (Table 5). The effect of sulphur fertilization was lower in 2011. Only the sulphur application in the form of solid fertilizer (var. 4) increased plant sulphur uptake. The total amount of sulphur intake per plant (variants 2,3) was lower than in control variant (var. 1). The highest uptake was observed during both years in var. 4. The application of YaraVita Thiotrac fertilizer also positively influenced plant characteristics after spraying fertilizer on leaves during the first productive fertilization. The sulphur content in wheat plants increased by $3.1 \%$ to $38.5 \%$ compared with the control variant (var. 1).

Lower effect of sulphur fertilizer application was observed in plant matter during the BBCH 65-70 growing stages (Table 6). The highest sulphur content in plant matter was found in variants 4 and 6 in 2011 after the application of YaraBela SULFAN and YaraVita Thiotrac fertilizer, while the uptake was highest in variants 5, 6. In 2012, sulphur content were significantly affected by the precipitation deficit, which occurred in May. The lack of water reduced leaching of sulphate anions outside the wheat root zone, which positively affected sulphur uptake found in the most of the variants.

Sulphur application increased the number of ears in 2011 and 2012. The highest number of ears was obtained in variants 5 and 6 in 2011. Sulphur fertilization increased the number of ears by $23 \%$ to $170 \%$ compared with the control variant. The highest numbers of ears found in the variants 5 and 6 in 2011 increased dry weight per plant.

Grain yield significantly differed in wheat harvested in 2011 and 2012 (Table 7). The highest grain yield was recorded in $2011\left(10.5-11.4 \mathrm{t}^{-h^{-1}}\right)$. In 2011 and 2012, the greatest effect of fertilization on grain yield occurred in var. 6 after the application of YaraBela SULFAN fertilizer and YaraVita Thiotrac sprayed in the late stages of vegetation (Table 7). The lowest grain yields were recorded in 2011 after YaraVita Thiotrac application (var. 3 and var. 4) during tillering phase.

Proportion of front grain significantly varied between 2011 and 2012. In 2011, specific weight values $\left(76.1-76.9 \mathrm{~kg} \cdot \mathrm{hl}^{-1}\right)$ were decreased due to rainy weather. The total rainfall in May 2011 was higher by $52 \mathrm{~mm}$ compared to May 2012. The sulphur fertilization had no effect on specific weight values (Table 7). Similarly, no effect of sulphur fertilization on Hagberg falling number was recorded. Protein content was slightly increased by the combination of YaraBela SULFAN and YaraVita Thiotrac fertilization, but differences among variants were not significant. Higher differences were found in Zeleny sedimentation volume, but the values also did not significantly differ among variants (Table 7). 
Table 4. Chemical composition of plant dry matter and sulphur uptake per plant during $\mathrm{BBCH} 28-30$ growing stages

\begin{tabular}{|c|c|c|c|c|c|c|c|c|c|}
\hline Year & Var. & $\begin{array}{c}\text { H1SR } \\
\mathrm{g}\end{array}$ & $\begin{array}{l}\mathrm{N} \\
\%\end{array}$ & $\begin{array}{l}\mathrm{P} \\
\%\end{array}$ & $\begin{array}{l}\mathrm{K} \\
\%\end{array}$ & $\begin{array}{l}\mathrm{Ca} \\
\%\end{array}$ & $\begin{array}{c}\mathrm{Mg} \\
\%\end{array}$ & $\begin{array}{l}\mathrm{S} \\
\%\end{array}$ & $\begin{array}{c}\text { Sulphur } \\
\text { uptake } \\
\text { per plant } \\
\text { mg }\end{array}$ \\
\hline \multirow[t]{2}{*}{2011} & 1 & $0.910^{\mathrm{b}}$ & $3.747^{\mathrm{a}}$ & $0.488^{\mathrm{a}}$ & $3.790^{\mathrm{a}}$ & $0.443^{\mathrm{a}}$ & $0.129^{\mathrm{a}}$ & $0.294^{a}$ & $2.675^{\mathrm{a}}$ \\
\hline & 2 & $1.197^{\mathrm{b}}$ & $3.570^{\mathrm{a}}$ & $0.519^{\mathrm{b}}$ & $4.084^{b}$ & $0.491^{\mathrm{a}}$ & $0.144^{\mathrm{b}}$ & $0.320^{\mathrm{a}}$ & $3.830^{\mathrm{b}}$ \\
\hline \multirow[t]{2}{*}{2012} & 1 & $0.586^{\mathrm{a}}$ & $5.071^{\mathrm{b}}$ & $0.482^{\mathrm{a}}$ & $4.908^{b}$ & $0.609^{b}$ & $0.121^{\mathrm{a}}$ & $0.417^{\mathrm{b}}$ & $2.444^{\mathrm{a}}$ \\
\hline & 2 & $0.691^{\mathrm{a}}$ & $4.965^{\mathrm{b}}$ & $0.522^{b}$ & $5.254^{\mathrm{b}}$ & $0.671^{\mathrm{b}}$ & $0.134^{b}$ & $0.453^{\mathrm{b}}$ & $3.130^{\mathrm{b}}$ \\
\hline
\end{tabular}

H1SR - dry weight per plant; values in one column labelled with various letters significantly differ on $p<0.05$

Table 5. Chemical composition of plant dry matter and sulphur uptake per plant during $\mathrm{BBCH} 39-43$ growing stages

\begin{tabular}{ccccccccc}
\hline Year & Var. & $\begin{array}{c}\text { H1SR } \\
\mathrm{g}\end{array}$ & $\begin{array}{c}\mathrm{N} \\
\%\end{array}$ & $\begin{array}{c}\mathrm{P} \\
\%\end{array}$ & $\begin{array}{c}\mathrm{K} \\
\%\end{array}$ & $\begin{array}{c}\mathrm{S} \\
\%\end{array}$ & $\begin{array}{c}\text { Sulphur } \\
\text { uptake } \\
\text { mg }\end{array}$ & $\begin{array}{c}\text { Number } \\
\text { of ears } \\
\text { per } 1 \mathrm{~m}^{2}\end{array}$ \\
\hline 2011 & 1 & $4.717^{\mathrm{d}}$ & $2.202^{\mathrm{a}}$ & $0.290^{\mathrm{b}}$ & $2.765^{\mathrm{a}}$ & $0.188^{\mathrm{a}}$ & $8.868^{\mathrm{c}}$ & $3.7^{\mathrm{d}}$ \\
& 2 & $3.816^{\mathrm{b}}$ & $2.533^{\mathrm{c}}$ & $0.328^{\mathrm{d}}$ & $3.160^{\mathrm{c}}$ & $0.213^{\mathrm{b}}$ & $8.128^{\mathrm{b}}$ & $3.3^{\mathrm{c}}$ \\
& 3 & $3.037^{\mathrm{a}}$ & $2.610^{\mathrm{d}}$ & $0.318^{\mathrm{c}}$ & $2.855^{\mathrm{b}}$ & $0.190^{\mathrm{a}}$ & $5.770^{\mathrm{a}}$ & $2.7^{\mathrm{a}}$ \\
& 4 & $4.233^{\mathrm{c}}$ & $2.370^{\mathrm{b}}$ & $0.274^{\mathrm{a}}$ & $2.778^{\mathrm{a}}$ & $0.216^{\mathrm{b}}$ & $9.143^{\mathrm{d}}$ & $3.1^{\mathrm{b}}$ \\
\hline 2012 & 1 & $1.829^{\mathrm{a}}$ & $2.877^{\mathrm{c}}$ & $0.260^{\mathrm{b}}$ & $3.312^{\mathrm{a}}$ & $0.296^{\mathrm{a}}$ & $5.414^{\mathrm{a}}$ & $2.1^{\mathrm{c}}$ \\
& 2 & $2.193^{\mathrm{c}}$ & $2.561^{\mathrm{a}}$ & $0.294^{\mathrm{c}}$ & $3.686^{\mathrm{d}}$ & $0.298^{\mathrm{a}}$ & $6.535^{\mathrm{c}}$ & $1.7^{\mathrm{a}}$ \\
& 3 & $1.917^{\mathrm{b}}$ & $2.623^{\mathrm{b}}$ & $0.269^{\mathrm{b}}$ & $3.571^{\mathrm{c}}$ & $0.296^{\mathrm{a}}$ & $5.674^{\mathrm{b}}$ & $1.8^{\mathrm{b}}$ \\
& $2.568^{\mathrm{d}}$ & $2.610^{\mathrm{b}}$ & $0.234^{\mathrm{a}}$ & $3.442^{\mathrm{b}}$ & $0.292^{\mathrm{a}}$ & $7.498^{\mathrm{d}}$ & $1.7^{\mathrm{a}}$ \\
\hline
\end{tabular}

H1SR: dry weight per plant; values in one column labelled with various letters significantly differ on $p<0.05$

\section{Discussion}

Sufficient sulphur supply during the growing period is necessary for the production of high quality grain. The most suitable are solid fertilizers containing sulphur in $\mathrm{SO}_{4}^{2-}$ anion forms in mixture with nitrate ions (Richter and Hlušek 1994). The positive effect of applied fertilizers was demonstrated by the results of plant analysis during BBCH 28-30 growing stages. Sulphur content in plant matter was increased after the application of sulphur fertilizer. Sulphur content present in the plant was relatively high $(0.294-0.453 \%)$ and recorded values are consistent with findings published by Fageria (2008) and Sahota (2006).

Dry weight per plant also increased after sulphur application, which corresponds with the conclusions published by Haneklaus and Schnug (1994). Sulphur uptake per plant increased only in var. 4 in 2011 while in 2012 the sulphur uptake per plant was coherent with the fertilizer application scheme. The application decreased the number of tillers and consequently the number of the unproductive tillers during late stages of vegetation $(\mathrm{BBCH}$ 
Table 6. Chemical composition of plant dry matter and sulphur uptake per plant during $\mathrm{BBCH} 65-70$ growing stages

\begin{tabular}{cccccccccc}
\hline Year & Var. & $\begin{array}{c}\text { H1SR } \\
\mathrm{g}\end{array}$ & $\begin{array}{c}\mathrm{N} \\
\%\end{array}$ & $\begin{array}{c}\mathrm{P} \\
\%\end{array}$ & $\begin{array}{c}\mathrm{K} \\
\%\end{array}$ & $\begin{array}{c}\mathrm{Mg} \\
\%\end{array}$ & $\begin{array}{c}\mathrm{S} \\
\%\end{array}$ & $\begin{array}{c}\text { Sulphur } \\
\text { uptake } \\
\mathrm{mg}\end{array}$ & $\begin{array}{c}\text { Number } \\
\text { of ears } \\
\text { per } 1 \mathrm{~m}^{2}\end{array}$ \\
\hline 2011 & 1 & $7.169^{\mathrm{d}}$ & $1.919^{\mathrm{d}}$ & $0.25^{\mathrm{e}}$ & $2.001^{\mathrm{bc}}$ & $0.109^{\mathrm{b}}$ & $0.122^{\mathrm{c}}$ & $8.746^{\mathrm{c}}$ & $690^{\mathrm{a}}$ \\
& 2 & $5.875^{\mathrm{b}}$ & $1.444^{\mathrm{a}}$ & $0.208^{\mathrm{a}}$ & $1.87^{\mathrm{a}}$ & $0.103^{\mathrm{a}}$ & $0.103^{\mathrm{a}}$ & $6.051^{\mathrm{a}}$ & $725^{\mathrm{b}}$ \\
& 3 & $6.325^{\mathrm{c}}$ & $1.729^{\mathrm{c}}$ & $0.224^{\mathrm{b}}$ & $2.045^{\mathrm{d}}$ & $0.125^{\mathrm{c}}$ & $0.111^{\mathrm{b}}$ & $7.021^{\mathrm{b}}$ & $730^{\mathrm{b}}$ \\
& 4 & $5.686^{\mathrm{a}}$ & $1.614^{\mathrm{b}}$ & $0.229^{\mathrm{c}}$ & $2.122^{\mathrm{e}}$ & $0.112^{\mathrm{b}}$ & $0.126^{\mathrm{d}}$ & $7.164^{\mathrm{b}}$ & $700^{\mathrm{a}}$ \\
& 5 & $9.693^{\mathrm{f}}$ & $1.659^{\mathrm{b}}$ & $0.224^{\mathrm{b}}$ & $1.965^{\mathrm{b}}$ & $0.102^{\mathrm{a}}$ & $0.111^{\mathrm{b}}$ & $10.76^{\mathrm{e}}$ & $750^{\mathrm{c}}$ \\
& 6 & $7.625^{\mathrm{e}}$ & $1.664^{\mathrm{b}}$ & $0.238^{\mathrm{d}}$ & $2.032^{\mathrm{cd}}$ & $0.102^{\mathrm{a}}$ & $0.128^{\mathrm{e}}$ & $9.76^{\mathrm{d}}$ & $735^{\mathrm{b}}$ \\
\hline 2012 & 1 & $4.82^{\mathrm{c}}$ & $1.914^{\mathrm{c}}$ & $0.211^{\mathrm{c}}$ & $1.69^{\mathrm{e}}$ & $0.161^{\mathrm{e}}$ & $0.211^{\mathrm{c}}$ & $10.17^{\mathrm{c}}$ & $442^{\mathrm{a}}$ \\
& 2 & $7.169^{\mathrm{d}}$ & $1.919^{\mathrm{d}}$ & $0.25^{\mathrm{e}}$ & $2.001^{\mathrm{bc}}$ & $0.109^{\mathrm{b}}$ & $0.122^{\mathrm{c}}$ & $8.746^{\mathrm{c}}$ & $690^{\mathrm{a}}$ \\
& 3 & $5.875^{\mathrm{b}}$ & $1.444^{\mathrm{a}}$ & $0.208^{\mathrm{a}}$ & $1.87^{\mathrm{a}}$ & $0.103^{\mathrm{a}}$ & $0.103^{\mathrm{a}}$ & $6.051^{\mathrm{a}}$ & $725^{\mathrm{b}}$ \\
& 4 & $6.325^{\mathrm{c}}$ & $1.729^{\mathrm{c}}$ & $0.224^{\mathrm{b}}$ & $2.045^{\mathrm{d}}$ & $0.125^{\mathrm{c}}$ & $0.111^{\mathrm{b}}$ & $7.021^{\mathrm{b}}$ & $730^{\mathrm{b}}$ \\
& 5 & $5.686^{\mathrm{a}}$ & $1.614^{\mathrm{b}}$ & $0.229^{\mathrm{c}}$ & $2.122^{\mathrm{e}}$ & $0.112^{\mathrm{b}}$ & $0.126^{\mathrm{d}}$ & $7.164^{\mathrm{b}}$ & $700^{\mathrm{a}}$ \\
& 6 & $9.693^{\mathrm{f}}$ & $1.659^{\mathrm{b}}$ & $0.224^{\mathrm{b}}$ & $1.965^{\mathrm{b}}$ & $0.102^{\mathrm{a}}$ & $0.111^{\mathrm{b}}$ & $10.76^{\mathrm{e}}$ & $750^{\mathrm{c}}$ \\
\hline
\end{tabular}

H1SR: dry weight per plant; values in one column labelled with various letters significantly differ on $p<0.05$

Table 7. Parameters of wheat grain quality

\begin{tabular}{llllcccc}
\hline Year & Var. & $\begin{array}{c}\text { Yield } \\
\mathrm{t} \cdot \mathrm{ha}^{-1}\end{array}$ & $\begin{array}{c}\mathrm{FG} \\
\%\end{array}$ & $\begin{array}{c}\mathrm{SW} \\
\mathrm{kg} \cdot \mathrm{h}^{-1}\end{array}$ & $\begin{array}{c}\mathrm{FN} \\
\mathrm{s}\end{array}$ & $\begin{array}{c}\text { Protein } \\
\%\end{array}$ & $\begin{array}{c}\text { SEDI } \\
\mathrm{ml}\end{array}$ \\
\hline 2011 & 1 & $11.2^{\mathrm{fg}}$ & $49.8^{\mathrm{bc}}$ & $76.9^{\mathrm{a}}$ & $259^{\mathrm{a}}$ & $12.0^{\mathrm{a}}$ & $50^{\mathrm{bc}}$ \\
& 2 & $11.1^{\mathrm{fg}}$ & $49.0^{\mathrm{b}}$ & $76.5^{\mathrm{a}}$ & $257^{\mathrm{a}}$ & $11.9^{\mathrm{a}}$ & $49^{\mathrm{b}}$ \\
& 3 & $10.5^{\mathrm{d}}$ & $49.5^{\mathrm{bc}}$ & $76.5^{\mathrm{a}}$ & $263^{\mathrm{a}}$ & $12.1^{\mathrm{ab}}$ & $50^{\mathrm{bc}}$ \\
& 4 & $10.6^{\mathrm{de}}$ & $54.3^{\mathrm{d}}$ & $76.1^{\mathrm{a}}$ & $229^{\mathrm{a}}$ & $12.2^{\mathrm{ab}}$ & $54^{\mathrm{d}}$ \\
& 5 & $11.0^{\mathrm{ef}}$ & $53.0^{\mathrm{cd}}$ & $76.4^{\mathrm{a}}$ & $238^{\mathrm{a}}$ & $12.0^{\mathrm{a}}$ & $53^{\mathrm{cd}}$ \\
& 6 & $11.4^{\mathrm{g}}$ & $50.0^{\mathrm{bc}}$ & $76.2^{\mathrm{a}}$ & $264^{\mathrm{a}}$ & $12.2^{\mathrm{ab}}$ & $50^{\mathrm{bc}}$ \\
\hline 2012 & 1 & $7.7^{\mathrm{a}}$ & $43.0^{\mathrm{a}}$ & $81.7^{\mathrm{b}}$ & $336^{\mathrm{b}}$ & $12.5^{\mathrm{bc}}$ & $43^{\mathrm{a}}$ \\
& 2 & $7.8^{\mathrm{ab}}$ & $44.0^{\mathrm{a}}$ & $81.2^{\mathrm{b}}$ & $330^{\mathrm{b}}$ & $12.7^{\mathrm{d}}$ & $44^{\mathrm{a}}$ \\
& 3 & $8.0^{\mathrm{bc}}$ & $43.3^{\mathrm{a}}$ & $81.3^{\mathrm{b}}$ & $341^{\mathrm{b}}$ & $12.7 \mathrm{~d}$ & $43^{\mathrm{a}}$ \\
& 4 & $7.7^{\mathrm{a}}$ & $41.0^{\mathrm{a}}$ & $81.6^{\mathrm{b}}$ & $326^{\mathrm{b}}$ & $12.6^{\mathrm{cd}}$ & $41^{\mathrm{a}}$ \\
& 5 & $8.1^{\mathrm{bc}}$ & $42.0^{\mathrm{a}}$ & $81.7^{\mathrm{b}}$ & $332^{\mathrm{b}}$ & $12.7^{\mathrm{d}}$ & $42^{\mathrm{a}}$ \\
& 6 & $8.3^{\mathrm{c}}$ & $43.3^{\mathrm{a}}$ & $81.6^{\mathrm{b}}$ & $316^{\mathrm{b}}$ & $12.7^{\mathrm{d}}$ & $43^{\mathrm{a}}$ \\
\hline
\end{tabular}

FG: proportion of front grain; SW: specific weight; FN: Hagberg falling number; Protein: protein content in dry matter; SEDI: Zeleny sedimentation volume; values in one column labelled with various letters significantly differ on $p<0.05$

65-70). The positive effect of applied sulphur on the number of productive tillers is in agreement with the results of Eriksen et al. (2001). The application of sulphur fertilizer increased the average number of ears per unit area by $14.0 \%$ and the average number of grains per ear by $18.6 \%$.

The application of sulphur fertilizers YaraBela SULFAN and YaraVita Thiotrac improved the plant nutrition demonstrated by greater grain quality. The grain yield was year 
dependent. In 2012, grain yield was decreased due to frost damage. The results confirmed the significant effect of weather conditions on grain quality previously described by Ducsay and Ložek (2004).

On haplic Luvisols (haLV), sulphur is known to increase the average yield by $21.7 \%$ (Järvan et al. 2012a). It was confirmed the time of fertilizer application is of a significant importance. The highest yield was obtained after the application of YaraBela SULFAN and YaraVita Thiotrac fertilizers in later stages of plant growth.

The proportion of front grain harvested in 2011 reached around $92 \%$ of the values measured in 2012. The proportion of front grain is in close relation with specific weight. The values of specific weight were decreased by high rainfall during the grain ripening in 2011. In 2012, grain specific weight was higher, but the differences between variants were not significant. The specific weight reached the values required $\left(78 \mathrm{~kg} \cdot \mathrm{hl}^{-1}\right)$ for wheat grain with high bread-making quality (Horáková 2010). The effect of sulphur fertilization on Hagberg falling number and protein content is not obvious. The values of Hagberg falling number significantly differed between 2011 and 2012. Hagberg falling number is known to be dependent on weather during the grain ripening and harvest (Perten 1964). Even if the difference between the values of Hagberg falling number were not significant, sulphur application decreased the values of Hagberg falling number with is in general agreement with the findings published by Schnug et al. (1993). Sulphur fertilization had a slight positive effect on grain protein content. The relation between fertilization, protein content and Hagberg falling number has been previously described. If the nitrogen obtained in the fertilizer is not incorporated into peptide chain the values of Hagberg falling number can be decreased (Randall and Wrigley 1986; Zhao et al. 1999a; Seling et al. 2006). This hypothesis is partially supported by the lower values of the Hagberg falling number obtained in 2012, variants 2, 4, 6. Contrarily, some papers (Schnug et al. 1993; Richter et al. 2001) described reverse correlation.

Even if sulphur fertilization slightly increased the values of protein content and Zeleny sedimentation volume, the effect was not significant which is not in agreement with the conclusions published by Randall and Wrigley (1986), Zhao et al. (1999a) and Hoel (2011).

\section{Acknowledgement}

This study was supported by the project IGA FA MENDELU No. IP 9/2012.

\section{References}

ČSN 461011-7 Testing of Cereals, Pulses and Oilseeds. Testing of Cereals. Determination of Proportion of Front Grains. 1988. Czech Standards Institute. Prague, Czech Republic. (in Czech)

Dämmgen, U., Walker, P., Grünhale, L., Jäger, H.J. 1998. The Atmospheric Sulphur Cycle. Sulphur in Agroecosystems. Kluwer Academic Publishers, Dordrecht, Netherlands, pp. 75-114.

Ducsay, L., Ložek, O. 2004. Effects of topdressing with nitrogen on the yield and quality of winter wheat grain. Plant Soil Environ. 50:309-314. 
Eriksen, J., Nielsen, M., Mortensen, J., Schjörring, J.K. 2001. Redistribution of sulphur during generative growth of barley plants with different sulphur and nitrogen status. Plant Soil 2:239-246.

Fageria, N.K. 2008. The Use of Nutrients in Crop Plants. CRC Press, Taylor and Francis Group, Boca Raton, USA, $430 \mathrm{pp}$.

Hagel, I. 2005. Sulphur and baking-quality of breadmaking wheat. Landbauforsch. Volk. 283:23-36.

Haneklaus, S., Schnug, E. 1994. Diagnosis of crop sulphur status and application of X-ray fluorescence spectroscopy for the sulphur determination in plant and soil materials. Sulphur in Agriculture 18:31-40.

Haneklaus, S., Murphy, D.P.L., Nowak, G., Schnug, E. 1995. Effects of the timing of sulphur application on grain yield and yield components of wheat. Z. Pflanz. Bodenkunde 158:83-85.

Hawkesford, M.J., De Kok, L. J. 2006. Managing sulphur metabolism in plants. Plant Cell Environ. 29:382-395.

Hoel, B.O. 2011. Effects of sulphur application on grain yield and quality, and assessment of sulphur status in winter wheat (Triticum aestivum L.). Acta Agr. Scand. B-S P 61:499-507.

Horáková, V. 2010. List of Recommended Varieties. Central Control and Testing Institute of Agriculture, Brno, Czeck Republic. 227 pp. ISBN 978-80-7401-027-9. (in Czech)

Hřivna, L., Richter, R., Ryant, P. 1999. Possibilities of improving the technological quality of winter wheat after sulphur fertilization. Zeszyty Naukowe Akademii Rolniczejim. H. Kollataja w Krakowienr. 349:143-150.

Hřivna, L., Richter, R. 2002. Diagnostic methods in nutrition of winter rape. Agrochémia 6:19-23. (in Czech)

ISO 7971-2. 1995. Cereals - Determination of Bulk Density, Called "mass per hectolitre" - Part 2: Routine Method. International Organization for Standardization. Geneva, Switzerland.

ISO 3093. 2004. Wheat, Rye and Respective Flours, Durum Wheat and durum Wheat Semolina - Determination of the Falling Number According to Hagberg-Perten. International Organization for Standardization. Geneva, Switzerland.

ISO 5529. 2007. Wheat - Determination of the Sedimentation Index - Zeleny Test. International Organization for Standardization. Geneva, Switzerland.

ICC standard No. 167:2000. Determination of Crude Protein in Grain and Grain Products for Food and Feed by the Dumas Combustion Principle. International Association for Cereal Science and Technology. Vienna, Austria.

Järvan, M., Edesi, L., Adamson, A. 2012a. The content and quality of protein in winter wheat grains depending on sulphur fertilization. Acta Agr. Scand. B-S P 62:627-636.

Järvan, M., Edesi, L., Adamson, A. 2012b. Effect of sulphur fertilization on grain yield and yield components of winter wheat. Acta Agr Scand. B-S P 62:401-409.

Johansson, E., Prieto-Linde, M.L., Svensson, G. 2004. Influence of nitrogen application rate and timing on grain protein composition and gluten strength in Swedish wheat cultivars. J. Plant Nutr. Soil Sci. 167:345-350.

Mathot, M., Mertens, J., Verlinden, G., Lambert, R. 2008. Positive effect of sulphur fertilisation on grasslands yields and quality in Belgium. Eur. J. Agron. 28:655-658.

Mengel, K. 1991. Ernährung und Stoffwechsel der Pflanze (Plant nutrition and metabolism). Gustav Fisher Verlag. Jena, Germany, 466 pp. (in German)

Perten, H. 1964. Application of the falling number method for evaluating alpha-amylase activity. Cereal Chem. 41:127-140.

Rasmussen, P.E., Ramig, R.E., Ekin, L.G., Rohde, C.R. 1977. Tissue analysis guidelines for diagnosis sulphur deficiency in wheat. Plant Soil 46:153-163.

Randall, P.J., Wrigley, C.W. 1986. Effects of the sulphur supply on the yield, composition and quality of grain from cereals, oilseed and legumes. In: Pomeranz, Y. (ed.), Advances in Cereal Science and Technology. Vol. VIII. AACC, St. Paul, MN, USA, pp. 171-187.

Richter, R., Hlušek, J. 1994. Plant Nutrition and Fertilization (I. General part). VŠZ Brno, Czech Republic, 77 pp. (in Czech)

Richter, R., Hřivna, L., Ryant, P., Šottníková, V. 2001. Effect of Sulphur Fertilization on Yield and Quality of Plant Foodstuffs. In: Proc. Conf. Rational Use of Fertilizers. CZU Prague, Czech Republic, pp. 62-69. (in Czech)

Sahota, T.S. 2006. Importance of Sulphur in Crop Production. Northwest Link. pp. 10-12. http://www.tbars.net/sulphur.pdf

Schnug, E., Haneklaus, S., Murphy, D. 1993. Impact of sulphur fertilisation on fertiliser nitrogen efficiency. Sulphur in Agriculture 17:8-12. 
Seling, S., Weigelt, W., Wissmeier, A.H. 2006. Bedeutung der Schwefeldüngung für Ertrag und Qualität von Weizen. Getreidetechnologie 60:148-152.

Shahsavani, S., Gholami, A. 2008. Effect of sulphur fertilization on breadmaking quality of three winter wheat varieties. Pakistan J. Biol. Sci. 11:2134-2138.

Zbíral, J. 2002. Analysis of Soil. Unified Workflows. Central Control and Testing Institute of Agriculture. Brno, Czech Republic, 197 pp. (in Czech)

Zbíral, J. (ed.) 2005. Analysis of Plant Material. Unified Workflows. Central Control and Testing Institute of Agriculture. Brno, Czech Republic, 192 pp. (in Czech)

Zhao, F.J., Hawkesford, M.J., McGrath, S.P. 1999a. Sulphur assimilation and effect on yield and quality of wheat. J. Cereal Sci. 30:1-17.

Zhao, F.J., Salmon, S.E., Withers, P.J., Monaghan, J.M., Evans, E.J., Shewry, P.R., McGrath, S.P. 1999b. Variation in the breadmaking quality and rheological properties of wheat in relation to sulphur nutrition under field conditions. J. Cereal Sci. 30:19-31.

Zörb, C., Grover, C., Steinfurth, D., Mühling, K.H. 2010. Quantitative proteome analysis of wheat gluten as influenced by $\mathrm{N}$ and $\mathrm{S}$ nutrition. Plant Soil 327:225-234. 